\title{
Concentration of Isotopes of Mercury in Countercurrent Molecular Stills ${ }^{12}$
}

\author{
By Samuel L. Madorsky, Paul Bradt, and Sidney Straus
}

\begin{abstract}
Mercury was refluxed in countercurrent molecular stills in order to concentrate ${ }^{204} \mathrm{Hg}$. Two glass stills, with heater and cooler placed outside the distillation columns, and one still, consisting of a glass column heated externally and a stainless-steel cooler placed concentrically inside the column, were used. As compared with a 10-cell steel column described previously, these columns showed poor performance, mainly because the hold-up was too small. There are definite indications, however, that with liquids having a lower surface tension than $\mathrm{Hg}$, these columns will perform as well as the 10-cell steel column. Mass-spectrometer analyses of isotope ratios of the $\mathrm{Hg}$-isotope concentrates were in good agreement with density determinations.
\end{abstract}

\section{Introduction}

In a previous paper $[1]^{3}$ concentration of the isotopes of mercury in a countercurrent molecular still has been described. The still consisted of a 10-cell metal column inclosed in a glass cylinder. The end fractions differed in density by a total of $161.6 \mathrm{ppm}$. The maximum change of density obtained per cell was about $18 \mathrm{ppm}$ as compared with a maximum value of about $24 \mathrm{ppm}$ obtained in a single-stage small glass still [2] or $23 \mathrm{ppm}$ obtained in a single-stage large steel apparatus [3]. One object of this investigation was to explore the possibility of obtaining by the same method a large separation of the isotopes of mercury by using long distillation columns with many cells. Another object was to compare density measurements of mercury-isotope concentrates with mass-spectrometer analysis of isotope ratios in the same concentrates.

${ }^{1}$ The work described in this paper was done in part under the auspices of the Atomic Energy Project.

2 The molecular stills used in concentrating mercury isotopes are similar in design to those developed in this laboratory by S. L. Madorsky, A. K. Brewer, and T. I. Taylor.

${ }^{3}$ Figures in brackets indicate the literature references at the end of this paper.
Ordinary mercury consists of a mixture of seven stable isotopes in the following proportions [4]:

\begin{tabular}{|c|c|}
\hline Isotope & Mole \% \\
\hline $196 \ldots$ & 0.15 \\
\hline $198 \ldots$ & 10. 1 \\
\hline $199_{\ldots}$ & 17. 0 \\
\hline $200_{\ldots}$ & 23.3 \\
\hline $201 \ldots$ & 13. 2 \\
\hline $202 \ldots$ & 29. 6 \\
\hline $204_{\ldots-\ldots}$ & 6. 7 \\
\hline
\end{tabular}

There has been of late a great deal of interest in the possibility of using pure isotopes of $\mathrm{Hg}$ of even atomic weight as a primary standard of wavelength of light [5]. Although ${ }^{200} \mathrm{Hg}$ and ${ }^{202} \mathrm{Hg}$ are the most abundant isotopes, it would be very difficult to separate them or even to concentrate them by countercurrent molecular distillation as this method is adapted primarily to the concentration of either the lightest or heaviest isotope from a mixture. The same argument holds for ${ }^{198} \mathrm{Hg}$. As to a choice between ${ }^{196} \mathrm{Hg}$ and ${ }^{204} \mathrm{Hg}$, it is obvious from the abundance table that ${ }^{204} \mathrm{Hg}$ is 
preferable because it is about 45 times as abundant as ${ }^{198} \mathrm{Hg}$. In view of these considerations, the main object of this investigation was the concentration of the heavy isotopes, particularly ${ }^{204} \mathrm{Hg}$.

\section{Distillation Columns}

The distillation columns used in this work are of two types: I, consisting of a glass tube, with heater and cooler placed outside the tube, figure 1; and II, consisting also of a glass tube and with heater placed outside, but with the cooler placed inside the tube, figure 2 . Both columns were kept at an angle of $7.5^{\circ}$ to the horizontal. They were provided with reservoirs at their upper ends so that only heavy fractions were concentrated at the lower ends. Inlets at the ends served for the introduction of the mercury and for drawing samples for analysis. The reservoirs were provided with side branch tubes surrounded with nichrome heating coils for the circulation of the mercury in the reservoirs. Evacuation was accomplished by means of an oil pump and $\mathrm{Hg}$-vapor pump, and a pressure of about $10^{-6} \mathrm{~mm}$ of $\mathrm{Hg}$ was maintained during the operation of the stills.

Column I, figure 1, was made of a glass tube with an internal diameter of $21 \mathrm{~mm}$. Indentations pressed into the tube on the underside, at right angles to the axis of the tube, formed individual cells, or cups. Roofs over these cups were formed on the upper side of the tube by indenting the glass in such a way that the condensate over each cup was delivered to the cup immediately above it in the series. Condensate on the sides of the column was guided from cell to cell in the upward direction by means of gutters pressed into the glass column. The column rested on a Nichrome electric heater. The roofs were cooled by means of a stream of tap water flowing over them in a trough. This trough was made by pressing lucite plates against the sides of the distillation column, with strips of sponge rubber between the lucite and the glass to make the joints watertight.

Column II, figure 2, was made of a glass tube $48 \mathrm{~mm}$ in inside diameter. The cups, or cells, were shaped in the same way as in column I. The condenser consisted of a series of metal plateroofs strung on a metal tube with tight-fitting sleeves as spacers. The metal tube was watercooled through a smaller concentric metal tube. The metal parts exposed to mercury were made of stainless steel. The column rested on a Nichrome electric heater. The sides and top were covered with an asbestos mat $2 \mathrm{~cm}$ thick in order to keep the column hot and to prevent the mercury vapor from condensing on the inner surface.

In addition to these two columns, a third column, III, similar to column I, but without a reservoir, was used in this work. In the absence of a reservoir a light concentrate could be collected at the upper end in addition to the heavy concentrate at the lower end. The cooler for this column, instead of a direct stream of water over the roofs, consisted of several long water-cooled copper tubes connected to two manifolds at the ends and placed over the column roofs. Contact between this cooler and the roofs was made by means of granular magnetic-iron oxide. The column was placed at an angle of $3.75^{\circ}$ to the horizontal. Characteristic details of the three distillation columns are given in table 1 .

TABLE 1. Details of molecular distillation columns used in concentrating isotopes of mercury

\begin{tabular}{|c|c|c|c|}
\hline Column & $\begin{array}{l}\text { Number } \\
\text { of cells }\end{array}$ & $\begin{array}{c}\mathrm{Hg} \text { in } \\
\text { each cell }\end{array}$ & $\begin{array}{l}\text { Angle to } \\
\text { hori- } \\
\text { zontal }\end{array}$ \\
\hline $\begin{array}{l}\text { I. All glass with reser- } \\
\text { voir }\end{array}$ & 66 & $g_{8}$ & $\begin{array}{c}\text { Degrees } \\
7.50\end{array}$ \\
\hline $\begin{array}{l}\text { II. Glass jacket reser- } \\
\text { voir, and internal } \\
\text { metal cooler }\end{array}$ & 110 & 12 & 7. 50 \\
\hline $\begin{array}{l}\text { III. All glass, without } \\
\text { reservoir }\end{array}$ & 150 & 8 & 3. 75 \\
\hline
\end{tabular}

\section{Temperature Measurements and Density Determinations of Fractions}

Operation of the columns could be observed and kept under control through a series of thermocouples placed on the outside of the columns at various points between them and the heaters. However, as pointed out in a previous paper [1], temperature measurements taken outside of the mercury pools proper are not indicative of the evaporation temperature of the mercury. The temperature was, therefore, calculated from the amount of heat carried off by the cooling water. This amount was determined by measuring the temperature of the inflowing and outflowing cooling water and its rate.

Density determinations were made by the same picnometer method described in a previous 

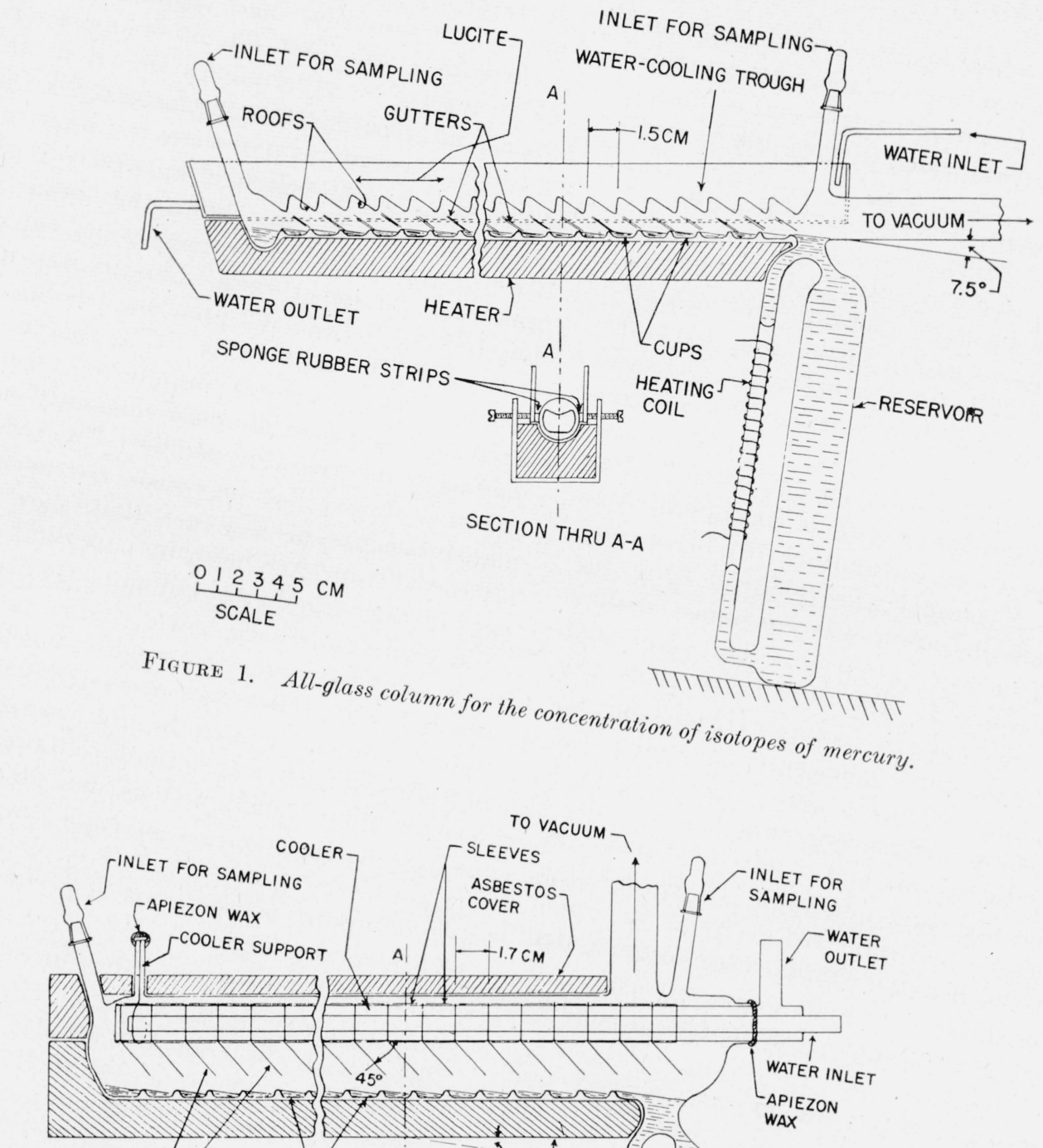

CONDENSING
PLATES
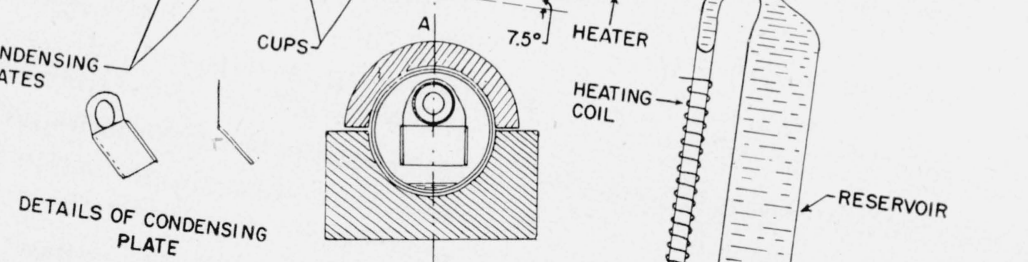

FIGURE 2.
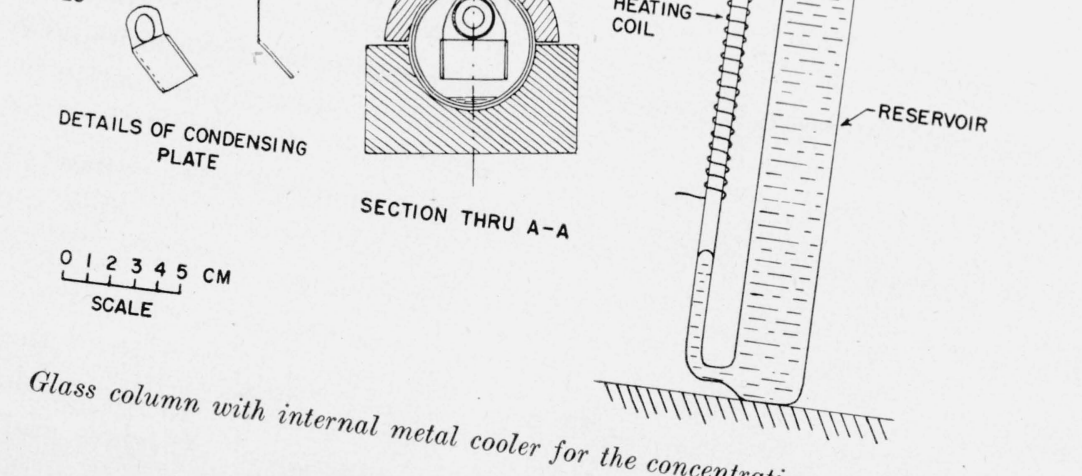

ntration of isotopes of mercury.

entration of Isotopes of Mercury 
paper [1]. In cases where operation of the column was resumed after sampling, the mercury samples were first returned to the respective end or reservoir of the column, from which they were removed.

\section{Experimental Work and Results}

Column I was operated at $74^{\circ} \mathrm{C}$ for $256 \mathrm{hr}$. The operation was then stopped and samples drawn from the lower end of the column and from the reservoir for density measurements. Operation of the column was then continued for another $681 \mathrm{hr}$, i. e., for a total of $937 \mathrm{hr}$. Column II was operated at $100^{\circ} \mathrm{C}$ first for $546 \mathrm{hr}$ and, after sampling from the lower end, it was operated at the same temperature for another $761 \mathrm{hr}$, a total of $1,307 \mathrm{hr}$. A sample was removed from the lower end, and operation was continued with a fresh batch of mercury at $76^{\circ} \mathrm{C}$. This run lasted $408 \mathrm{hr}$, and a sample was then taken from the lower end of the column. Column III was operated at $100^{\circ} \mathrm{C}$ for three consecutive periods, 243, 500 , and $507 \mathrm{hr}$. Samples were taken from both ends of the column after each period.

Experimental details and results of density determinations are shown in table 2 . In columns I and II, which had large reservoirs at the upper ends, only the heavy isotopes were concentrated at the lower ends. The highest concentrations obtained were +117.3 and $+107.0 \mathrm{ppm}$, in columns I and II, respectively. In column III, which was without a reservoir, the greatest difference in density between the light and heavy fractions

TABLE 2. Experimental details and results

\begin{tabular}{|c|c|c|c|c|c|c|c|}
\hline Column & $\begin{array}{l}\text { Exper- } \\
\text { iment }\end{array}$ & $\begin{array}{l}\text { Hg in } \\
\text { reser- } \\
\text { voir or } \\
\text { upper } \\
\text { end of } \\
\text { column }\end{array}$ & $\begin{array}{c}\mathrm{Hg} \text { in } \\
\text { lower } \\
\text { end of } \\
\text { col- } \\
\text { umn. } \\
\text { Heavy } \\
\text { frac- } \\
\text { tion }\end{array}$ & $\begin{array}{c}\text { Dura- } \\
\text { tion of } \\
\text { experi- } \\
\text { ment }\end{array}$ & $\begin{array}{l}\text { Tem- } \\
\text { pera- } \\
\text { ture }\end{array}$ & $\begin{array}{l}\text { Change } \\
\text { in den- } \\
\text { sity of } \\
\text { light } \\
\text { frac- } \\
\text { tions }\end{array}$ & $\begin{array}{l}\text { Change } \\
\text { in den- } \\
\text { sity of } \\
\text { heavy } \\
\text { frac- } \\
\text { tions }\end{array}$ \\
\hline \multirow[t]{2}{*}{ I } & $\begin{array}{l}1 \\
2\end{array}$ & $\begin{array}{c}g \\
2,100 \\
2,100\end{array}$ & $\begin{array}{l}g \\
74 \\
74\end{array}$ & $\begin{array}{l}h r \\
256 \\
a 937\end{array}$ & $\begin{array}{c}{ }^{\circ} \mathrm{C} \\
64 \\
66\end{array}$ & $\begin{array}{c}p p m \\
0 \\
0\end{array}$ & $\begin{array}{r}\text { ppm } \\
72.0\end{array}$ \\
\hline & 1 & 2,400 & 100 & 546 & 78 & --.-- & 53.7 \\
\hline \multirow[t]{2}{*}{ II } & 2 & 2,400 & 100 & ${ }^{a} 1,307$ & 78 & --.-- & 107. 0 \\
\hline & 3 & 2,400 & 76 & 408 & 67 & ---- & 91.6 \\
\hline \multirow{3}{*}{ III } & 1 & 91 & 100 & 243 & -.-- & -56.1 & 48.8 \\
\hline & 2 & 91 & 100 & a 743 & -.-- & -102.8 & 86.9 \\
\hline & 3 & 91 & 100 & a 1,250 & --.- & -89.8 & 105.1 \\
\hline
\end{tabular}

a Cumulative time including the hours of the experiment immediately above them. was about $190 \mathrm{ppm}$. As seen from table 2 , countercurrent fractionation had apparently reached equilibrium in the first $700 \mathrm{hr}$ of operation.

The results of experiments shown in table 2 indicate an unsatisfactory performance for all the columns. A comparison of these results with those obtained in the 10-cell steel apparatus [1], under equilibrium conditions, shows that while in the 10-cell column change of density per cell was 18 ppm, the change in these columns was approximately $0.8,1.0$, and $3.2 \mathrm{ppm}$ per cell for columns I, II, and III, respectively. The inability of the all-glass and glass-metal columns described here to separate isotopes of mercury efficiently can be explained in the following manner. The cells in these columns should not be considered as individual plates because of the fact that they were not separated from each other by partitions as was the case in the 10-cell steel column. The vapor over each pool of mercury had a chance to mix freely with the vapor over the neighboring pools above and below it. However, even under these conditions there should have been a greater separation of isotopes than was actually obtained. Even if two or three cells acted as one plate, the total change in density, for example, in column III should have been $(150 / 2) \times 18=1,350$ or $(150 / 3) \times$ $18=900 \mathrm{ppm}$, on the basis of performance of the 10-cell steel column.

The chief difficulty was due, undoubtedly, to the small capacity of the mercury cups in the cells. This capacity was about $0.6 \mathrm{ml}$ in columns $\mathrm{I}$ and III and about $0.9 \mathrm{ml}$ in column II. In view of the high surface tension of $\mathrm{Hg}$ and its inability to wet glass, it did not drain regularly and uniformly from cup to cup along the column, so that some pools were filled more than others by as much as 100 percent or even more and some pools were observed to stay altogether empty for several hours at a time. In case of the 10-cell steel apparatus, where each cell had a capacity of about $9 \mathrm{ml}$, these irregularities of counterflow were minimized by the large volume of the liquid in each cell. In the present columns, where the capacity of each cell was from $1 / 15$ to $1 / 10$ of that in the 10 -cell steel column, these irregularities had a critical effect on the operation. All-glass and glass-metal columns similar to those described in this paper were used for refluxing liquids with normal surface tension and having the ability to wet glass. On the basis 
of 2 to 3 cells operating as one complete plate, these columns performed as well as the 10-cell steel column, where each cell operated as a plate.

\section{Mass-Spectrometer Analysis of Isotopic Ratios of Mercury Concentrates}

Measurements of mercury isotope ratios were made on a $60^{\circ}$ Nier type [6] mass spectrometer provided with a "continuous balance" recording potentiometer. The ionization chamber was constructed of copper; however, the copper ionrepeller, being in direct path of the $\mathrm{Hg}$ vapor beam, was replaced, as a precautionary step, with a fine platinum gauze.

The inlet system was in the form of a glass manifold to which six sample tubes could be attached. Each sample tube consisted of a 3-mm inside diameter tube attached to a $1-\mathrm{cm}$ inside diameter tube, the small tube ending inside the larger tube in the form of a sealed capillary breakoff projection. The $\mathrm{Hg}$ sample was introduced into the smaller tube through an open end. This end was then sealed to an evacuation system, the tube evacuated to about $10^{-6} \mathrm{~mm} \mathrm{Hg}$. and then sealed off so as to enclose the $\mathrm{Hg}$ sample. The sample tube was then sealed on to the manifold by its 1-cm inside diameter open end. Admission of mercury vapor from the sample tube into the mass spectrometer was accomplished by dropping a magnetically manipulated iron ball, about 0.8 $\mathrm{cm}$ in diameter on the capillary break-off, inside the large part of the sample tube.

After evacuating the mass spectrometer and before dropping the iron ball on the break-off, the manifold was flamed until the largest peak on the $\mathrm{Hg}$ background was a small fraction of the recorder scale at the highest recorder sensitivity. The sample tube was then immersed in liquid air, the iron ball dropped on the break-off, and pumping continued for some time. The liquid air was then replaced with a freezing mixture at $-23^{\circ} \mathrm{C}$, and the measurements of isotope ratios were carried out while the sample was kept at this temperature. When a set of measurements was completed, the freezing mixture was replaced with liquid air again, and the smaller part of the sample tube holding the $\mathrm{Hg}$ sample was sealed off. Whenever necessary, venting of the mass-spectrometer chamber was accomplished by cracking off the manifold and not by opening a stopcock beyond the mercury-vapor pump and liquid-air trap, as is usually done in vacuum work. In this way the mass-spectrometer chamber remained free of $\mathrm{Hg}$ contamination from outside sources.

Analysis was made by successively comparing the heights of the recorder peaks from ${ }^{198} \mathrm{Hg}$ to ${ }^{202} \mathrm{Hg}$ with that of ${ }^{204} \mathrm{Hg}$. For each comparison the sequence, zero- ${ }^{204} \mathrm{Hg}$-zero-peak-zero- ${ }^{204} \mathrm{Hg}$-zero, was run 10 times, the scanning rate being set to cause the recorder pen to linger several seconds at the tip of each peak.

Eight samples of normal $\mathrm{Hg}$ were analyzed, and the average isotope ratios are shown in table 3 in comparison with those of Nier [4]. There seems to be a very good agreement between the two sets of ratios. No attempt was made to determine ratio ${ }^{196} \mathrm{Hg} /{ }^{204} \mathrm{Hg}$, since the height of the ${ }^{196} \mathrm{Hg}$ peak is only about 2 percent of the ${ }^{204} \mathrm{Hg}$ reference peak. The presence of a memory effect was checked by comparing analyses of five normal samples, each following analysis of a heavy sample, with those of three normal samples, each following a light sample. The small differences found were in the opposite direction to that which a memory effect would indicate. The results of all the iostope ratio determinations are shown in table 4 .

Densities of the various mercury concentrates were calculated on the basis of the isotope ratios shown in table 4. A comparison between the experimentally determined density deviations of the concentrates from normal $\mathrm{Hg}$ and those calculated is given in table 5. On the basis of data in table 4, concentrations of ${ }^{204} \mathrm{Hg}$ in samples III-3-L and III-3-H are found to be 6.684 and 6.899. This gives a total enrichment of ${ }^{204} \mathrm{Hg}$ in the lowest cell of column III over that in the uppermost cell of 4.66 percent.

TABLE 3. Abundance ratios of $\mathrm{Hg}$ isotcpes

Comparison between the present work and that of Nier

\begin{tabular}{|c|c|c|c|}
\hline \multirow[b]{2}{*}{ Ratio measured } & \multicolumn{3}{|c|}{ Values of isotope ratio } \\
\hline & $\begin{array}{l}\text { Present } \\
\text { work }\end{array}$ & $\begin{array}{l}\text { Nier's } \\
\text { work }\end{array}$ & $\begin{array}{l}\text { Percent- } \\
\text { age } \\
\text { devia- } \\
\text { tion }\end{array}$ \\
\hline $196 / 204 \ldots$ & - n... & 0.022 & (n.... \\
\hline $198 / 204 \ldots$ & 1. 527 & 1. 507 & -1.3 \\
\hline $199 / 204 \ldots \ldots$ & 2. 553 & 2.537 & -0.6 \\
\hline $200 / 204 \ldots \ldots$ & 3.487 & 3.467 & -.6 \\
\hline $201 / 204$ & 1. 971 & 1. 965 & -.3 \\
\hline $202 / 204 \ldots \ldots$ & 4. 401 & 4. 405 & +.1 \\
\hline
\end{tabular}


TABLE 4. Mass spectrometer analysis of isotope ratios in mercury concentrates

\begin{tabular}{|c|c|c|c|c|c|c|c|}
\hline \multirow{2}{*}{ Sample } & \multirow{2}{*}{$\begin{array}{l}\text { Num- } \\
\text { ber of } \\
\text { dupli- } \\
\text { cates } \\
\text { ana- } \\
\text { lyzed }\end{array}$} & \multicolumn{6}{|c|}{ Isotope ratios in normal $\mathrm{Hg}$ and in concentrates } \\
\hline & & $196 / 204^{\mathrm{a}}$ & $198 / 204$ & $199 / 204$ & $200 / 204$ & $201 / 204$ & $202 / 204$ \\
\hline III-3-Lb & 5 & 0.0231 & 1. 572 & 2. 619 & 3.525 & 2.005 & 4. 426 \\
\hline Normal_.. & 8 & .0224 & 1. 527 & 2. 553 & 3.487 & 1.971 & 4. 401 \\
\hline II-1-H & 3 & .0213 & 1. 475 & 2. 493 & 3. 390 & 1.925 & 4. 374 \\
\hline II-3-H & 3 & .0210 & 1. 450 & 2.456 & 3. 383 & 1.923 & 4. 371 \\
\hline III-3-H & 7 & .0206 & 1. 436 & 2.425 & 3.341 & 1. 907 & 4. 365 \\
\hline $\mathrm{II}-2-\mathrm{H}$ & 3 & .0206 & 1. 433 & 2. 435 & 3. 320 & 1. 905 & 4. 363 \\
\hline
\end{tabular}

a Ratio 196/204 for normal $\mathrm{Hg}$ is that given by Nier, all the other ratios in this column were estimated by assuming that the amount of concentration of a given isotope was proportional to difference between the molecular weight of this isotope and the average molecular weight of $\mathrm{Hg}$. This relationship was found to be approximately true for the other light isotopes.

b Roman numeral stands for column, arabic number for experiment, and $\mathrm{L}$ and $\mathrm{H}$ for light and heavy fraction (see table 2).

TABLE 5. Comparison between experimental density values and those calculated from isotoxe ratio data for $\mathrm{Hg}$ concentrates

\begin{tabular}{|c|c|c|c|}
\hline \multirow{2}{*}{ Sample } & \multicolumn{2}{|c|}{$\begin{array}{l}\text { Deviation of den- } \\
\text { sity from normal, } \\
\text { in ppm }\end{array}$} & \multirow{2}{*}{$\begin{array}{l}\text { Percent- } \\
\text { age } \\
\text { differ- } \\
\text { ence }\end{array}$} \\
\hline & $\begin{array}{l}\text { Experi- } \\
\text { mental }\end{array}$ & $\begin{array}{l}\text { Calcu- } \\
\text { lated }\end{array}$ & \\
\hline III-3-L & -89.8 & -86.1 & -4.2 \\
\hline $\mathrm{II}-1-\mathrm{H}_{\ldots} \ldots \ldots$ & +53.7 & +76.8 & +43.0 \\
\hline $\mathrm{II}-3-\mathrm{H}_{\ldots} \ldots \ldots$ & +91.6 & +100.1 & +9.2 \\
\hline III $-3-\mathrm{H}_{\ldots} .$. & +105.1 & +104.9 & -1.9 \\
\hline $\mathrm{II}-2-\mathrm{H}_{-} \ldots \ldots$ & +107.0 & +103.3 & -4.4 \\
\hline
\end{tabular}

\section{Conclusions}

Concentration of ${ }^{204} \mathrm{Hg}$ in long countercurrent molecular distillation columns having small cups of less than $1 \mathrm{ml}$ capacity, gave poor results, as compared with a 10-cell steel column with large cups, described in a previous publication. The chief reason lies in the fact that, because of the small hold-up in the cells, a liquid like $\mathrm{Hg}$, with a very high surface tension did not reflux regularly, so that individual cells held more liquid at one time than at another. There are indications, however, that with liquids of normal surface tension, 2-3 cells in such columns act as one plate, comparable with one cell in the 10-cell steel columns. The all-glass and glass-metal columns described in this paper are more easily constructed and, where the liquid has a normal surface tension and refluxes regularly, a smaller hold-up is more advantageous.

Mass Spectrometer analyses of isotope ratios in normal $\mathrm{Hg}$ gave results that are in good agreement with those obtained by Nier. The mass spectrometer isotope enrichment determinations agree fairly well with direct density measurements by the picnometer method.

The authors thank F. L. Mohler for many valuable suggestions in connection with this investigation and C. E. Emery, Jr., who assisted with the operation of the mass spectrometer.

\section{References}

[1] A. K. Brewer and S. L. Madorsky, J. Research NBS 38, 129 (1947) RP1764.

[2] R. S. Mulliken and W. D. Harkins, J. Am. Chem. Soc. 44, 37 (1922).

[3] W. D. Harkins and S. L. Madorsky, J. Am Chem Soc. 45, 591 (1923).

[4] A. O. Nier, Phys. Rev. 52, 933 (1937).

[5] William F. Meggers, Rev. Mod. Phys. 14, 59 (1942).

[6] O. E. Nier, Rev. Sci. Inst. 11, 212 (1940).

Washington, March 26, 1948. 